\title{
Land, territory and commons: voices and visions from the struggles
}

Tomaso Ferrando, Isabel Álvarez Vispo , Molly Anderson, Sophie Dowllar , Harriet Friedmann , Antonio Gonzalez , Chandra Maracle \& Nora McKeon

To cite this article: Tomaso Ferrando , Isabel Álvarez Vispo, Molly Anderson, Sophie Dowllar, Harriet Friedmann , Antonio Gonzalez, Chandra Maracle \& Nora McKeon (2020): Land, territory and commons: voices and visions from the struggles, Globalizations, DOI: 10.1080/14747731.2020.1783819

To link to this article: https://doi.org/10.1080/14747731.2020.1783819

曲 Published online: 07 Jul 2020.

Submit your article to this journal $\sqsubset$

Q View related articles ¿

View Crossmark data $₫$ 


\title{
Land, territory and commons: voices and visions from the struggles
}

\author{
Tomaso Ferrando (10), Isabel Álvarez Vispo ${ }^{b}$, Molly Anderson (10) , Sophie Dowllard, \\ Harriet Friedmann ${ }^{\mathrm{e}}$, Antonio Gonzalez ${ }^{\mathrm{f}}, \mathrm{Ch}^{\mathrm{a}}$ dra Maracle ${ }^{\mathrm{g}}$ and Nora McKeon ${ }^{\mathrm{h}}$
}

${ }^{a}$ Institute of Development Policy and Law and Development Research Group, University of Antwerp, Antwerp, Belgium; ${ }^{b}$ URGENCI International and Comunaria, Basque Country; ${ }^{C}$ Middlebury College, Middlebury, USA; ${ }^{d} 5$ C's Theatre Collective and Mamma Africa Community Centre, Nairobi, Kenya; ${ }^{\mathrm{e} T o r o n t o ~ F o o d ~ P o l i c y ~ C o u n c i l ~ a n d ~ U n i v e r s i t y ~ o f ~ T o r o n t o, ~ T o r o n t o, ~}$ Canada; ${ }^{\mathrm{f} C o l e c t i v o ~ A g r o e c o l o ́ g i c o ~ A j ~ M a y o n, ~ T z ' u t u j i l ~ a n d ~ K a q c h i k e l ~ T e r r i t o r y, ~ S o l o l a ́, ~ G u a t e m a l a ; ~}{ }^{9} \mathrm{Kakhwa}$ 'on:we/Real People Eat Real Food, Grand River Territory at Ohsweken, Ontario, Canada; ${ }^{\text {h}}$ Rome 3 University, IUC Turin and Terra Nuova, Rome, Italy

\begin{abstract}
All over the world, financial capitalism and extractivism are appropriating land as if it was nothing more than a commodity, a mere 'factor' of production that can be exploited to generate financial returns. Movements and activists are organizing, resisting, protecting and promoting life-giving visions against this continuous enclosure of living beings and paces: they use their bodies, laws, educational projects, histories and visions to regain control over territory as a political space, self-determine and create solidarities. In the act resistance, they are the target of moral, physical and legal violence. They and their ideas are criminalized, disciplined, punished and in some cases exterminated. In this contribution, activists from the Basque Country, Guatemala, Kenya and the Six Nations and a group of academics get together to learn from each other, support the ongoing search for common vocabularies and identify possible milestones of a coordinated and international strategy for a lifeenhancing future.
\end{abstract}

\section{KEYWORDS}

Land; territory; social movements; indigenous visions; commons; commoning

\section{Introduction: a dialogue across experiences and disciplines on the re-appropriation of land and territory}

Land is increasingly subjected to dispossession, enclosure and appropriation under contemporary financialized capitalism. ${ }^{1}$ The convergence in recent decades between corporate interests, financial capital and the policies of states and international organizations has imposed a vision of land as an asset: land as 'real estate' is a commodity on the market. This vision has turned the cultural, historical and ecological complexity of the web of life into resources to exploit for profit. ${ }^{2}$ Against this trend, counter-movements of peoples, communities, activists, academics and some politicians have taken shape at the local level. They defend rights of people, culture, and nature, and construct foundations for more harmonious and equitable futures. ${ }^{3}$ In their visions and practices, the struggle is not for land alone, but for territory as a political, cultural and dynamic concept that links people with one another and with all beings.

This article has been constructed in six months of conversations between October 2019 and February 2020. We brought together academics and activists to create opportunities for mutual teaching and learning, and to jointly think about shared vocabularies that could identify a common 
ground for solidarity and organization. We hope that organizing these conversations into this text might inspire deeper questions and wider dialogues. Most of all, our aim was and is to facilitate more coordinated action in defense of territories central to societies, identities and cultural ways of living in and with the web of life.

The dialogue has been structured around four local contexts where land and territory are the object of financial speculation, capitalist expansion and the reduction of nature into 'factors of production' for capitalist accumulation. These are realities where individual authors are actively engaged, so the group had access to direct accounts of the ways in which capital and finance are changing the relationship between humans, land and territory and of how people are organizing to defend and construct. Together we reflected on the roles of historical and contemporary structures of oppression, and the possibility for linking local and global forms of organization and resistance. The emotions and dynamics that are unfolding on the ground helped to redefine the content of the interactions that we are reporting in this paper. One point of interest at the start of our discussions concerned law and commons as possible forms of resistance against the enclosure of places and territories and sources of inspiration in reclaiming and reinventing people's visions of the future. ${ }^{4}$ As we moved forward in our conversation, we found ourselves talking about other themes, such as sovereignty and oppression, time and resistance, violence, fear and tiredness. More generally, we considered the need to - using Antonio's words: 'act within the constraints and limits of the present without losing sight of the long-term goal of radical transformation of dominant socio-economic structures'.

Sophie brought to the floor two different streams of resistance in Kenya: urban dwellers are opposing the destruction of public parks to build large-scale 'development' projects framed as 'Nairobi of tomorrow'; and rural communities are fighting against the privatization of ancestral land for international tourism. Antonio taught us about the struggle of indigenous communities in Guatemala, where centuries of territorial and cultural colonization have appropriated the land, the minds and the future of almost half of the population. This means that resistance must take place at multiple levels, not only at the frontline of appropriation but also in supporting cultural understanding and social solidarity. Chandra shared with us the unique perspective of the Haudenosaunee in Ontario (central Canada), presently centred on Six Nations Reserve, and the use of food, conviviality, law and politics in their fights for land, territory and spirituality. They must do this in a context marked by five centuries of settler colonialism, broken promises and erasure of existing forms of governance, law, language, and ecological knowledge and practices. Finally, Isa from the Basque Country enriched the conversation with the point of view of the Comunaria collective, which is active in Spain to build 'New Commons' from a feminist and communal perspective. Land and diversity (both cultural and biological) are two of the 'New Commons' that have been enclosed and taken away from smallholders and families and that Comunaria is fighting for.

The sections that follow are brief snapshots of our broad and holistic conversations. The image that emerges is that of a global movement of privatization and appropriation of land that is supported by multiple forms of violence and reshapes local lives and places. Against this, counter-movements organize around these same territories and mobilize multiple strategies to work towards longterm emancipation in ways as diverse as their cultures and landscapes (Polanyi, 2001). The dialogue that we report in this article shows that this double movement of resistance and envisioning better futures is strengthened when social movement and academics engage with each other and cooperate directly on the ground (Borras, 2016).

This article contains accounts and reflections on ongoing situations. However, it was written before the coronavirus pandemic spread across the world, reaching the regions where the activists live and where the struggles described take place. We decided not to change the original structure 
of our contribution since it reports veraciously on the exchange and analysis in which we engaged. However, the intensity of the health and socio-economic crisis along with the severity of the public response - in the form of lockdown, militarization, use of the state of emergency, curfew, and other measures - are significantly affecting the rights and the organizational capacity of social movements and may represent a blow to the political achievements obtained in the last years.

\section{Fear and tiredness in the face of violence}

When the frontline activists among us spoke, the group realized that their voices were full of hope, energy and determination. Every day, relentless struggle against the commodification of land and simplification of landscapes are taking place. People across the globe are resisting now, in the present, because they are aware of the urgent need - and possibility - for another relationship between humans and the earth - Mother Earth for some, commons for others, ancestral territories for still others. However, when we tell and listen to stories of marches, pickets, mobilization and organization, we cannot ignore the accounts of violence, fear, oppression, invisibility and tiredness that accompany them.

Violence assumes different forms and is shaped by contexts. Everywhere, mental and physical harm limits people's capacities to organize and mobilize. In some cases, violence is military repression, coups d'état and incarceration. In other contexts, it is perpetrated through legislation, unequal access to justice, austerity and the dismantlement of the welfare state. Often, violence is cultural, moral, and divisive, singling out groups for their class, gender and race (Crenshaw, 1989). Indigenous people in Guatemala are not only attacked by soldiers, but also treated as people who are incapable of understanding modernity. Smallholders in the Basque Country are not only losing their land to creditors but are also required to wear 'traditional clothes' when they sell products at the market, so that tourists can have the experience of the traditional countryside. In both contexts, violence is used to impose a vision of land and territory that fits the interests of private accumulation. Material and cultural violence is a tangible and intangible weapon used to dismantle the ecological and horizontal relationships among people and with all other beings inhabiting their places.

Violence is often proportional to the level of organization that communities have achieved. It is mostly orchestrated by the state through its legal and regulatory systems. Top-down decisions are implemented with little or no consultation with local people or concern for local realities. Extractive plunder, modernity, economic growth and export-led 'development' are imposed on people and their territory as if they were the sole possible script. Jurisdiction, sovereignty and public powers help to expand the frontier of global capitalism, enclosing spaces, cultures, and lives. They expel people and push them into urban and suburban places, so-called 'reserves' and 'protected areas' where they 'can live their life without obstructing economic development and growth'. ${ }^{5}$ In the best scenario, the state is silent and therefore complicit, relying on 'rule of law' to support dispossession; in the worst scenario, the state is actively involved in supporting the commodification of land by police violence against occupiers defending land, or by failure to enforce legal protections of threatened people (Mattei \& Nader, 2008).

Despite the increasing oppression and, in the case of Latin America, the militarization of a whole continent, groups, communities and people continue to organize around their own visions, paradigms and principles. Strategies differ and there are diverging approaches to interaction with law, politics and state institutions. Some use their common history and the link between a place and collective identity. Others use agro-ecology, food, and conviviality as opportunities to bring people together, get to know each other, and learn about the importance of sharing their place on earth. Most use social media as a form of outreach, mobilization and creation of a counter-narrative. 
Our cases show different combinations of small-scale grassroots projects and mass protests and civil disobedience.

Along with the strategies deployed on the ground, also language varies. Sometimes different meanings are attributed to the same word. For example, the experience of Comunaria in the Basque Country is constructed around 'commons' and commoning as intellectual and practical alternatives to commodification, privatization and exploitation of nature (See Polanyi, 2001). In other contexts, the vocabulary of 'commons' and 'commoning' is new and exogenous and people are rather inspired by ecological visions of humanity as embedded within nature or by their territories as places requiring regeneration out of 'respect for our ancestors' bones and love for the faces of the children to be'. ${ }^{6}$ Despite the differences in terminology, the shared aim is to strengthen the ties that keep people together and reinforce the idea that we all belong to a territory that is co-constructed with nature; it is not an empty space that can be appropriated, traded, exploited and discarded.

\section{Uniting around the struggle for land while engaging in the more ambitious project of recuperating the territory}

In Guatemala, Kenya, the Six Nations and the Basque Country alike, movements coalesce around specific acts of violence against their land that act as catalysts. By identifying a cause and an 'enemy', movements can bring people together, orient strategy and define concrete goals that can be achieved. Violence may take the form of the large-scale projects in Guatemala, the construction of the new highways in the centre of Nairobi, the replacement of small-scale agriculture with industrial complexes or large-scale agribusiness in the Basque Country, the relocation of indigenous communities or the encroachment on the territory of the Six Nations. Despite strong unity among people and organizations, divisions, cooptation, differences and struggles are frequent in all contexts (Hall, 2015). Sometimes the 'enemies' that push back are within our movement, our own societies. Blockage of our ideas and claims can also come in the academic world where we operate. Therefore, we recognize the importance for all of us - movements, peoples and individuals - to be self-aware, to self-educate, collaborate, dialogue, accept disagreement and diversity, and to establish relationships based on reciprocal learning and listening.

In the four experiences at the centre of this paper, resistance against the enclosure of a specific tract of land, water source, seeds or ancestral practices brings people together. However, the horizon of the struggle a longer one, because places are much more than a point on a map and natural elements are much more than objects. The long-term struggle is linked with the preservation and construction of spaces of autonomy, self-determination and emancipation from commodification and appropriation in which peoples can strengthen their visions based on horizontality, equality, restorative and inter-generational justice and nurturing the ecosystem of which we are a part (Zibechi, 2010). Seen from the frontline, land and territory are not synonymous. However, the protection of the former goes hand-in-hand with the construction of the latter and the possibility of imagining non-commodified spaces of collective well-being (Zibechi, 2012).

In Guatemala, movements organize around the goal of land rights and self-determination in the context of a plurinational state based on indigeneity. Similarly, movements in Nairobi that are fighting to maintain two urban parks open to the public the importance that these places have in the construction of political and cultural identity of the post-colonial country. In the Basque Country, Comunaria's fight for food sovereignty and access to land for agroecological production is also a struggle to re-build social ties and collective interactions that have been fractured and wiped out by the entrenchment of commodification, productivism and consumerism. In the Six 
Nations territory, all forms of Haudenosaunee resistance are embedded in the long-term horizon of independence and emancipation from the multiple legacies of settler colonialism, and the consolidation of territories organized around indigenous principles, laws and relations.

\section{The material and cultural legacy of colonialism and the double process of decolonization}

From our conversations, it was clear that territory is a political, cultural and dynamic concept expressing the relationship between people, nature and place. ${ }^{7}$ All struggles for territory are informed by history, particularly how the past shapes multiple understandings of the present and possibilities for the future. Colonial legacies have an impact on contemporary social and ecological relations and, as a result, define the contexts in which movements are conceiving and seeking self-determination and collective emancipation. The material and immaterial consequences of the colonial project and of imperialistic policies are severe and enduring. However, there are also more contemporary forms of colonization, for instance the colonization of the mind by an artificially constructed infinite consumer desire, that often affect the Global North as much as the Global South (Maldonado-Torres, 2007; Quijano, 2000; Quijano, 2007).

The dismantling of past and ongoing forms of colonization is central to the construction of just futures (Arrighi, 1994; Patel \& Moore, 1983; Wallerstein, 1983). In our dialogue, we recognized the importance of distinguishing between the material and cultural implications of colonialism and to look for points of convergence and solidarity across geographies and movements. Alternative visions of the world must be embedded in redressing centuries of colonial plunder and decades of continuing appropriation guaranteed by the postcolonial states (De Sousa Santos, 2007; Mignolo, 2007; Mignolo, 2011).

In Guatemala, the past is as a series of enclosures, expulsions and appropriations from the colonial conquest to the opening of world trade (Sassen, 2014). Therefore, awareness of the past and redress of injustices justify contemporary re-occupations of land: indigenous who are trespassing are not stealing land, they are reclaiming what has been taken away from them across centuries of violence and subordination. They are reclaiming land and re-establishing respectful, lively connections between people and all other beings in the land. In Kenya, the colonial legacy is materially experienced through the artificial boundaries of the nation state and the unequal allocation of land across tribes and people. However, history is also a compilation of memories of the anti-colonial struggle and the victories, which movements try to make visible, remember, and share as they challenge ideologies of power and property. In the defense of Uhuru park in Nairobi, grassroot movements recuperated images and accounts of the anti-colonial fights and made visible the central role that this place played in the struggle for liberation ('Uhuru') from colonial rule. These stories and political connections act as social glue that brings people together against the possibility of new evictions and privatization because they show that it is not 'only' about the land, but about identity, community and belonging.

The present of the Haudenosaunee is deeply rooted in colonial wars between Britain and the U.S. Six Nations reserve was land granted by British Canada to indigenous people originally living in what is now New York state in return for support against the United States in the American Revolution. That land is well situated but - in contrast to land granted to European settlers called 'United Empire Loyalists' - over time became much smaller than the original grant. Today's struggle for land is thus based on that betrayal and the breach of a promise for land and autonomy: it is a fight against centuries of social and cultural subordination, notably the suppression of Mohawk and other indigenous 
languages and cultural practices, and the ignoring of indigenous laws originally built into treaties. In the Basque Country, the process of industrialization and developmental policies of the Franco dictatorship led to the loss of arable land and small-scale agriculture to the benefit of large-scale agribusinesses and industrial complexes that have completely changed the landscape and the relationship between humanity and nature. Developmentalism was the visible part of a deeper transformation that was imposed with the tools of cultural and political repression. The present landscape is the outcome of specific legal, political and economic decisions taken over the years. Seen through this lens it ceases to seem inevitable, normal and immutable.

Along with its material implications, the legacy of the violent past is also a mental scar inflicted by cultural homogenization, identity erasure, indoctrination to modernity, socio-economic marginalization and dismantling of communities. This makes it harder to organize around a common cause and feeling of belonging. Any movement and any form of organization that aims at proposing noncapitalist and non-extractivist visions of the interdependence between society and nature must face this colonization of their own minds and the sense of impotence, impossibility and inevitability that it generates (Baldwin, 1962; Fanon, 1963; Mbembe, 2013).

As an example, in Guatemala, the three waves of colonization are felt to have created a fracture between campesinos and indigenous people: indigenous knowledge and indigenous lives were treated as inferior, and members of indigenous communities were pushed into embracing non-indigenous identities for the sake of safety life and social acceptance. In Kenya, colonization created tensions between tribes; that legacy become evident in violence during the recent elections and may continue to compromise the ability of social movements to organize a unique voice against exploitation.

For Six Nations, cultural colonialism not only produced hierarchy and subordination, but tried to erase the history that predates settler colonialism. In those centuries there were also political problems and dark ages, but Haudenosaunee had a highly sophisticated legal system, a strong sense of collectivity and sharing. They implemented practices we would now call agro-ecological and the capacity of living together with each other and with the earth. The principles of this legal system were and are still based in respect for each other expressed through care for the ancestors and future generations. In the Basque Country, the political project of 'modernity' that is fostering infinite consumer desires has been internalized by rural citizens, who are increasingly abandoning their territory. Social ties constructed around food production have been dismantled and the few remnants of territorial connections have been converted into folklore to be sold and performed in food fairs by means of traditional costumes and traditional food.

De-colonization of the mind grows out of reconstructing the vision and social relations of territory as a political, ecological and collective space (Shiva, 1993). This can take the form of a renewed pride in indigenous identities and practices, the redefinition of socio-legal systems around principles like 'Buen Vivir', the adoption of a feminist approach that directly challenge the patriarchal and individualist ideologies of global capitalism. In Guatemala and the Six Nations, de-colonization takes the shape of new educational curricula, indigenous schools and bottom-up initiatives where new generations are exposed to a different knowledge than the colonizers'. They learn about their people, their identity and the cosmovisions that see human and non-human beings as dynamically interconnected and interdependent across spaces and times. In Kenya, the current social fractures are tackled by invoking past resistance movements that were capable of reconnecting people based on a holistic vision of the collective right to the self-determination, free from colonial masters and colonial ties. In the Basque Country, Comunaria's struggle for food sovereignty against the disappearance of the rural territory has been supported by the adoption of a strong feminist, anti-capitalist and collective approach to nature and society which is manifested by getting together into safe places, such 
as houses, warehouses, and squares. People from all generations are reminded of the importance of caring for themselves and for others rather than competing; they learn about agroecology and experience how collaboration, sharing and participation can assert collective rights to land, seeds, food processing, and knowledge; they build cooperative forms of economic organization. based on sharing, ecology and equality.

\section{Law and the struggle for land and territory: oppression, conscious interventions and subversive legal imaginaries}

In the struggle for land and territory, state law and legal systems are perceived as a double-edged sword: they are a tool of the oppressing state - to 'legitimate' violence and repress alternative visions - but they also offer some spaces for resistance and legitimize political victories (Mattei \& Nader, 2008). Law identifies the areas that will be 'developed' by the investors and authorizes their enclosure, privatization, and dispossession, which forces abandonment of the collective ways in which people inhabit the land. National and local authorities also use law to criminalize counter-movements and the implementation of their counter-visions. Even before the exceptional Covid-19 lockdown, 'law and order' has been instilled in laws, regulations, administrative acts and police action to prevent activism and spontaneous organizations that do not fit with the structure and form of the modern state. Law, which is constructed around dichotomies, separations and an obsessive view of 'progress', tends to be oblivious to the historical, social and ecological complexity of life (Mattei \& Capra, 2015; Moore, 2015).

Overall, movements share a clear understanding of the double nature of state law. By leveraging legal opportunities to protect their land and territory, they may at the same time legitimize the very institutionalized structures of oppression they are fighting (Anghie \& Chimni, 2003; Callinicos, 2009; Harvey, 2004; Marks, 2003). Sometimes, legal tools are used as a complement or an alternative to putting bodies in danger through direct confrontations, that is, as a tool that does not expose activists to physical harm. In those cases, the risk of legitimizing an oppressive legal structure can be minimized by adopting specific and focused legal actions and framing them in the broader vision of longterm emancipation and self-determination. Legal activism works best when it is characterized by a strong awareness of the limited potential of the legal apparatus to redress the systemic challenges faced by movements and peoples (Ferrando, 2017).

Aware of the potential and - increasingly - of the limits of law, movements are leveraging international law, the human rights framework and national administrative regulation to challenge further privatization, resist evictions, and protect the life of people and Pachamama. Engaging with state law and legal processes is tiresome, time-consuming, expensive and mainly a last resort. It may support defensive strategies but cannot lead to new paradigms and ecological visions. In the struggle for land in Guatemala, Kenya, the Six Nations and the Basque Country, peoples and movements experiment with different legal layers - from the international to the local - with the hope that limited, focused interventions may tactically rebalance power among states, investors and communities (Bourdieu, 1987; Tsing, 2002).

In Guatemala, for example, communities and activists access courts to obtain enforcement of the right to Free Prior Informed Consent contained in The Indigenous and Tribal People Convention of the International Labor Organization (169/ILO), or to prevent violation of Constitutional principles or the breach of local administrative procedure in making a private concession to capitalist investors. In the Basque Country, the most recent intervention involved a strategic use of local 'land banks', an institution created by city councils and local Governments to increase smallholders' access to public 
and private land that had been abandoned for years. The movements wanted to make sure that the promise would be fulfilled. Rather than directly challenge the cities' governments, they signed up all interested people to the bank's waiting list. This targeted and non-confrontational use of the legal opportunity made the existing needs visible and highlighted their importance, with the hope that eventually land would be made available.

Beyond legal mainstream, there are 'subversive' approaches to law and legal systems. These ways of engaging with law do not accept the constraints of the formal legal system, which is based not on redistribution but on giving 'enough' to people to survive (Brinks et al., 2019; Moyn, 2018). They take the form both of elaborating an alternative interpretations of the existing structures and consolidating alternative legal systems that operate outside of the dominant jurisdictional framework. In Guatemala, for example, social movements engaged in the protection of seeds from patent claims decided to teach lawyers about their life cycle and the way in which they would normally produce and reproduce. The lawyers could then make legal arguments aligned with the ecological cycle of the 'web of life', rather than the commodification of seeds and enclosure of life (Capra, 1997; Moore, 2015). This victory was profound because it refused dominant legal interpretation of life and nature as objects. ${ }^{8}$

Moreover, movements are joining forces with sympathetic lawyers and academics to diffuse and strengthen bottom-up, opposing conceptions of law, state and the nation. Their aim is to build ways of practicing and thinking about law that are de-linked with the dominant legal framework and are aligned with the social and environmental needs and aspirations of people. Often, this process consists in recovering forms of governance that existed before the colonial era and strengthening bottom-up legitimacy by means of education and practice. In Guatemala, Maya law and Maya legal structures are taught, elaborated and promoted by members of the communities who have been educated in mainstream law schools and are inspired by the principles of 'Buen Vivir', plurinationalism, horizontality, duty towards people and nature and the rights of future generations. Similarly, Six Nations' organizations and individuals are working to rehabilitate the sophisticated legal structures and forms of governance in place before the arrival of settlers and the subordination of the people and the territories to the settler state. The process of bottom-up legal recovery is crucial to the construction of alternative societies. It contributes to intellectual emancipation from colonial ways of thought. This suggests the need for more alliances between people seeking decolonization and lawyers and educators in mainstream institutions (from primary schools to universities). These people can challenge dominant conceptions of law to promote ecological and cultural rules that serve people and planet (Mama \& Anderson, 2016; Mignolo, 2011).

\section{Multiple vocabularies, common objectives}

What has emerged from our conversations is the need for global solidarity that supports the distinctiveness of local struggles and aspirations towards life-enhancing futures. Before turning to this in the final section of this paper, we want to address the question whether a common language could strengthen transnational ties and facilitate the exchange of information, ideas, and visions.

Given the increasing importance attached to the notions of 'commons' (comunes) and 'common goods' (bienes communes) and commoning in Europe and North America, we asked ourselves whether they could be considered part of a shared vocabulary (De Angelis, 2017; Federici, 2019). These terms are ways of describing ways of life and forms of organization much older and deeper than private property and the state. What are the possibilities and risks behind the use of these words as a lingua franca to represent visions and practices based on social collaboration and 
ecological respect? We were aware of the linguistic differences, so we were not looking for unquestioned use of the idea of 'commons'. Our intention was to look for commonalities across ideas and practices.

When we introduced the ideas of 'commons' and 'common goods', we were not surprised to find that the words are not in general use and even have the potential to reproduce the epistemological division between Europe (in particular the urban movements) and the rest of the world. On the one hand, Comunaria in the Basque Country has embraced the idea of the 'New Commons' and commoning as approaches to nature and each other that are de-commodified, anti-patriarchal and anticapitalist. On the other hand, the notions of commons and commoning do not have the same relevance in Guatemala, Kenya or among the Haudenosaunee people, where the principles and objectives of 'commons' may correspond abstractly to how people live, but the word is seldom used (in Kenya, mainly with regard to water) or arouses resistance because it comes from elsewhere (in Guatemala).

From our conversations, we concluded that the terms 'commons' and 'common goods' are not universal and do not resonate with all geographies and contexts. As such, the term should not be used uncritically by outsiders to define dynamics and context that resemble or have elements that 'look like' realities and situations that have been defined as 'commons' elsewhere. Moreover, we were confronted with the incompatibility between the idea of common 'goods' and a vision of nature that is not external to society and is not composed of items/goods/resources that can be managed, controlled and organized by humans. Both the idea of 'commons goods' and of 'common-pool resources' thus need to be carefully reconsidered in light of the risk of imposing and dismantling the rich complexity of visions and epistemologies (De Sousa Santos, 2014; De Sousa Santos, 2018; Escobar, 2018).

At the same time, we perceived a high level of congruence between the conceptions of the 'commons' and 'commoning' adopted by Comunaria (anti-capitalist, anti-privatization, conviviality, collectivity, horizontal self-organization, ecological redistribution, consideration for the past, present and future generations, agro-ecology, etc.) and the conceptual framework adopted by the other movements to describe their own engagement with people and nature. In the Mayan context, for example, the notion of 'natural elements' is used to define both humans and all the other components of the web of life and to strengthen their interdependence and equality. This appears to be similar to the notion of 'commoning' in that it requires humans to continuously construct, enact and adopt social practices that respect the horizontal relationship between human and nonhuman beings. Similarly, the Haudenosaunee philosophy of life is built around the idea of sharing equally and respecting the ecological balance of nature. In Chandra's words: 'Haudenosaunee thinking is all about the commons as it is not an "other": there was not a place set aside for royalty and another for peasants or whoever'. These deeply democratic social relations are embedded in the web of life, which includes all living and non-living beings. This can be grasped, for example, in the words of the Ohen:ton Karihwatekhwen Kanonhweratonhseraor, the Thanksgiving Address, a 'universal idea of acknowledging all that exists in nature and which assists us with our existence as human beings and our responsibilities to them'. It is also expressed by the Haudenosaunee legal concept of 'One Dish and One Spoon': meals are prepared respecting the life cycle of nature and will be eaten by everyone, so everyone has to take only what is needed, keep the dish clean and make sure that there will always be something for the others.

If we need a shared vocabulary, we can start by looking at the concepts that have been proposed by communities and social movements and that are used by activists all across the planet. The words food sovereignty and agroecology, for example, are bottom-up expressions of farmers' and peasants' aspirations and practices that have created significant convergences and are widely accepted across 
the globe (Borras \& Franco, 2012; Dalla Costa, 2007). In addition, visions like 'Buen Vivir' and 'One Dish and one Spoon' have the merit of promoting political projects based on de-commodification, anti-patriarchy and de-colonization which can be leveraged to address the current economic structure, to redress historical legacies and to build a society based on respect for the web of life.

\section{Interacting and learning from one another: engagement across experiences and disciplines and co-construction of new political and conceptual spaces}

The present article is not an end but a beginning. We have not tried to provide solutions. We wanted to give continuity to the Siena process and use these conversations to create bridges within and between people and movements, and across academic disciplines and geographies. As indicated in the introduction, we wanted to create opportunities for mutual teaching and learning. We aimed at identifying shared ways of thinking across geographies and struggles to inspire more questions, more conversations and facilitate more coordinated action in defense of territories.

On the way forward, we want to strengthen the engagement between activists and academics, given that the latter are too often secluded in ivory towers with the knowledge gained within social movements and brought forward in distinct cultures. Voices, bodies and actions of resistance against the privatization and enclosure of land and life are multiplying. Activists, communities and social movements are at the forefront of the struggle in both cities and the countryside. The aim is not to 'let' people who are active in the territories speak, because they already speak (unless they are violently silenced) (Morris, 2010). It is about listening, creating the conditions where people can listen to each other and so deepen solidarity. Knowledge about territories and visions of the 'web of life' are constantly generated and reproduced by peoples all over the world. History, culture, lives, actions, experience and accumulated wisdom are a repository of unique and diverse ecological knowledge. It is our goal to widen and deepen their recognition by opening the ears of people who have failed to listen.

Academics can play a role in joining, fostering and facilitating dialogue across movements and social actors. They shall act as allies in the struggle, support existing interaction and the elaboration of collective ideas and processes, and use their position, privilege and opportunities to nourish, strengthen and consolidate ideas that support resistance to expropriation and the deepening of new ways of living. More importantly, academics shall avoid temptations of 'intellectual extractivism' to further their careers; instead, their research and engagement should aim for solidarity with people's movements, reflect people's experiences and memories, and enhance their understanding of the powers ranged against them.

Our conversations also revealed that a shared vocabulary and shared strategies might play an important role in consolidating solidarity and enhancing separate efforts across cultures and places. The idea of 'territorial emancipation', although not specifically mentioned during our conversation, might fit with what the activists on the ground were evoking: this identifies the achievement of a political, geographical and cultural space where communities can self-organize and renew historically defined ecological relationships among themselves and with the web of life that they are part of. 'Territorial emancipation' could identify the shared aspiration of the movements involved in the project and open interesting opportunities for trans-disciplinary engagement and solidarity (Zibechi, 2012).

'Territorial emancipation' and the construction of life-enhancing societies requires at least three conditions: relaxation of the pressure and violence suffered by activists and local movements and consolidation of ongoing struggles in defense of land; creation of conditions where people can get together, think collectively and share visions about the present and future of the living world; ${ }^{9}$ 
and an intensification of dialogue between engaged academics and movement intellectuals to coconstruct new ideas and practices that can be deployed across the world and strengthen actions undertaken on the ground.

Use of formal legal institutions for 'territorial emancipation' may be relevant but only if fully understood in their ambivalence and deployed with tactical awareness and the full support of the communities. On the one hand, legal activism can be used with attention and care to touch the most sensitive nerves of the legal system and provoke a positive ripple effect (Isa called this an 'acupuncture use of the law'). On the other hand, legal systems and sovereign powers also legitimate violence against communities and movements, so that the use of legal tactics may reproduce the idea of the modern state as 'sovereign' over the idea and the practices of a territory.

There will likely be space to deploy 'commons' and 'commoning' as ideas and forms of political organization aimed at reversing the process of commodification of lives and nature and creating spaces of reciprocity, respect and balance. Yet, it is important to recognize that these terms are not clearly defined and understood even in Europe (where they are most used) and that they are exogenous to most of the movements in other parts of the world.

All over the world, capitalism and finance are dismantling the ecological complexity of territories and extracting what they want from them. Narratives and practices implement a monotone understanding of 'territory' that reduces nature and people to 'factors' of capitalist production (De Sousa Santos, 2002; Escobar, 2004; Rajagopal, 2003; Shiva, 1993). Against the continuous enclosure of living beings and places, movements and activists are organizing, protecting and promoting life-giving visions: they use their bodies, laws, educational projects, histories and visions. Because of their resistance, they suffer moral, physical and legal violence. They and their ideas are criminalized and even exterminated. In this context, academics and social movement intellectuals must work together, learn from each other, and support the ongoing search for shared vocabularies and coordinated strategies for a life-enhancing future.

\section{Notes}

1. On the global rush to land, see, Franco et al. (2013), FIAN International, Margulis et al. (2013), Sassen (2013), White (2012).

2. On commodification, see, among others, Kelly and Peluso (2015), Sammond (2007). On commodification and financialization of land, see Ferrando (2018).

3. On social movements and resistance against land grabbing, see, among others, Franco (2008), Morden (2015), Tarrow (1994), Zibechi (2010).

4. On commons and commoning see, De Angelis (2017), Federici (2019), Vivero-Pol et al. (2018).

5. Interview with Antonio González, November 2019.

6. Interview with Chandra, January 2020.

7. On the difference between space and territory and the political nature of the latter, see, among others, Harvey (2001), Lefebvre (1976a), Lefebvre (1976b).

8. For a critique of civil society's acceptance of the vocabulary and paradigm of global finance, see Cerrato and Ferrando (2020).

9. For example, each movement has been involved in the implementation of grassroots educational projects that consolidate and diffuse political notions and different visions of the future. For example, Kenyan activists have been organizing political training camps for young feminists; Communaria as a rural/ urban collective in the Basque Country has been hosting tailleres and collective moments to consolidate food sovereignty through activism, technical support and consultation. In Guatemala, May indigenous communities have established Maya schools where students unlearn the dominant accounts of history, geography and humanity and are exposed to alternative and socio-geographically defined visions of the relationship between people and the planet. In the Six Nations, food and food sovereignty projects have 
been launched by activists to strengthen the conviviality among members of different groups and between people and the surrounding world.

\section{Disclosure statement}

No potential conflict of interest was reported by the author(s).

\section{Notes on contributors}

Tomaso Ferrando is Professor of Global Justice at the University of Antwerp (Law and Development Research Group and Institute of Development Policy). He holds a PhD in Law from Sciences Po University Law School and has previously worked as lecturer at the Universities of Bristol Law School and Warwick School of Law. His research focuses on the intersection between law, food systems, food sovereignty and finance. He teaches in Law and Food Systems, has been legal consultant to the former United Nations Special Rapporteur on the Right to Food, Professor Hilal Elver, and cooperates with food-related civil society organizations at the national and international level.

Isabel Álvarez Vispo is an educator, agroecological farmer and researcher. Daughter and granddaughter of peasants, she lives in the countryside of the Basque Country. She is the Vice-President of the URGENCI International network (a Community-supported agricultural network) and part of the Comunaria Network and of the Research and Investigation Network REDINAM, which supports municipalism. She is an activist in Baladre, a Coordinator of multiple struggles against social exclusion. She is particularly involved in creating spaces for education and support to people interested in agroecological transitions and in political activism at the local and international level. In the last years, Isabel has published several researches and contributed to publications concerning agroecology, commons, municipalism and feminism.

Molly Anderson is the William R. Kenan Jr. Professor of Food Studies at Middlebury College in Vermont, where she teaches about food security, the right to food, agroecology and sustainable food systems. She works from the local to the international level with organizations dedicated to transforming food systems toward greater ecological integrity, equity and justice.

Sophie Dowllar Ogutu is a mother, an unapologetic women's rights defender, a community mobilizer and organizer, and above all - a feminist artist. She is a key coordinator of The 5 C's Theatre Collective and cofounder of the Mamma Africa Community Centre, a board member of the Kenya Community Media Network (KCOMNET) and also sits in the International women playwrights board since this year (2020). She is a mentor with the Girl's Brigade, and the principal organizer for SWAN Day Kenya. As grassroots feminist, Sophie has been a member of the International Committee Member for the World March of Women representing Africa since 2013.

Harriet Friedmann is a long time Toronto Food Policy Councillor and Professor Emerita of Sociology, University of Toronto. She is co-developer of the historical food regimes approach, and contributor to debates on family farming, metabolism of city-food regions, and emergent food system governance, including the Global Report of the International Assessment of Agricultural Science and Technology for Development (IAASTD). Her current project is Global Political Ecology of Food. She received the 2011 Lifetime Achievement award by the Canadian Association of Food Studies, and her lifetime continues. www.harrietfriedmann.ca.

Antonio González, Maya Kaqchikel, is a member of the Colectivo Agroecológico Aj Mayon (Agroecological Collective Aj Mayon), an indigenous and campesino local organization in Guatemala and member of the Political Council of the Movimiento Agroecológico de América Latina y el Caribe (Agroecological Movement of Latin American and Caribe - MAELA).

Chandra F. Maracle is the mother of four daughters. She is founder of Kakhwa'on:we/Real People Eat Real Food, exploring links between food, art, language, people, technology and land. She is coordinator of Tyonnhehkwen Onkwaya'takenha:tshera food and nutrition, at Skaronhyaseko:wa/ Everlasting Tree School and is currently a PhD student in the Faculty of Environmental Studies at York University. Chandra lives on the Six Nations of the Grand River Territory. 
Nora McKeon studied history and political science before joining the UN Food and Agriculture Organization, where she was responsible for opening up the institution to cooperation with organizations of small-scale producers and civil society. She now engages in research, writing, teaching, and advocacy around food systems, peoples' movements, and governance issues. She closely follows evolutions in global food governance including the reformed UN Committee on World Food Security. She teaches at Rome 3 University and the International University College of Turin, and serves as technical adviser to the West African network of small-scale producers.

\section{ORCID}

Tomaso Ferrando (D) http://orcid.org/0000-0001-7034-3592

Molly Anderson (D) http://orcid.org/0000-0001-7717-1025

\section{References}

Anghie, A., \& Chimni, B. S. (2003). Third world approaches to international law and individual responsibility in internal conflicts. Chinese Journal of International Law, 2(1), 77-103. https://doi.org/10.1093/ oxfordjournals.cjilaw.a000480

Arrighi, G. (1994). The long 20th century. Money, power, and the origins of our times. Verso.

Baldwin, J. (1962). The fire next time. Dial Press.

Borras, S., \& Franco, J. (2012). A 'land sovereignty' alternative? Towards a people's counter-enclosure. TNI Agrarian Justice Programme.

Borras, S. M. (2016, April 14). Land politics, agrarian movements and scholar-activism. Inaugural Lecture (Transnational Institute).

Bourdieu, B. (1987). The force of law: Toward a sociology of the juridical field. Hastings Law Journal, 38, 109248.

Brinks, D., Dehm, J., \& Englle, K. (2019). Introduction: Human rights and inequality, Humanity, Winter.

Callinicos, A. (2009). Imperialism and global political economy. Polity.

Capra, F. (1997). The web of life. Anchor.

Cerrato, D., \& Ferrando, T. (2020). The financialization of civil society activism: Sustainable finance, nonfinancial disclosure and the shrinking space for engagement. Accounting, Economics and Law: A Convivium. https://doi.org/10.1515/ael-2019-0006

Crenshaw, K. (1989). Demarginalizing the intersection of race and sex: A black feminist critique of antidiscrimination doctrine, feminist theory and antiracist politics. University of Chicago Legal Forum, 1(8), 139-167. https://chicagounbound.uchicago.edu/uclf/vol1989/iss1/8

Dalla Costa, M. (2007). Food sovereignty, peasants and women. The Commoner. Retrieved March 10, 2020. https://docplayer.net/121404253-Food-sovereignty-peasants-and-women.html

De Angelis, M. (2017). Omnia sunt communia. On the commons and transformation to postcapitalism. Zed Books.

De Sousa Santos, B. (2002). Toward a new legal common sense: Law, globalization, and emancipation. Cambridge University Press.

De Sousa Santos, B. (2007). Beyond abyssal thinking: From global lines to ecologies of knowledge. Revista Critica de Ciencias Sociais, 30(1). https://www.jstor.org/stable/40241677

De Sousa Santos, B. (2014). Epistemologies of the South: Justice against epistemicide. Routledge.

De Sousa Santos, B. (2018). The end of the cognitive empire: The coming of age of epistemologies of the south. Duke University Press.

Escobar, A. (2004). Beyond the third world: Imperial globality, global coloniality, and anti-globalization social movements. Third World Quarterly, 25(1). https://doi.org/10.1080/0143659042000185417

Escobar, A. (2018). Designs for the pluriverse: Radical interdependence, autonomy, and the making of worlds. Duke University Press.

Fanon, F. (1963). Black skin, white mask. Penguin.

Federici, S. (2019). Re-enchanting the world: Feminism and the politics of the commons. PM Press. 
Ferrando, T. (2017). Land rights at the time of global production: Leveraging multi-spatiality and 'legal chokeholds'. Business and Human Rights Journal, 2(2), 275-295. https://doi.org/10.1017/bhj.2017.13

Ferrando, T. (2018). The financialization of the transnational food chain: From threat to opportunity? Transnational Legal Theory, 9(3-4), 316-342. https://doi.org/10.1080/20414005.2018.1563434

FIAN International. The business of land in Matopiba, Brazil. https://www.fian.org/en/struggle/the-businessof-land-in-matopiba-brazil

Franco, J. (2008). Making land rights accessible: Social movements and political-legal innovation in the rural Philippines. The Journal of Development Studies, 44(7), 991-1022. https://doi.org/10.1080/ 00220380802150763

Franco, J., Borras, S., Alonso-Fradejas, A., Buxton, N., Herre, R., Kay, S., \& Feodoroff, T. (2013). The global land grab: A primer, revised edition, TNI Agrarian Justice. Transnational Institute.

Hall, R. (2015). Resistance, acquiescence or incorporation? An introduction to land grabbing and political reactions 'from below'. The Journal of Peasant Studies, 42(3-4), 467-488. https://doi.org/10.1080/03066150. 2015.1036746

Harvey, D. (2001). Spaces of global capitalism: Towards a theory of uneven geographical development. Verso.

Harvey, D. (2004). The 'new' imperialism: Accumulation by dispossession. Socialist Register, 40, 63-87. https:// socialistregister.com/index.php/srv/article/view/5811

Kelly, A. B., \& Peluso, N. L. (2015). Frontiers of commodification: State lands and their formalization. Society \& Natural Resources, 28(5), 473-495. https://doi.org/10.1080/08941920.2015.1014602

Lefebvre, H. (1976a). Reflections on the politics of space. Antipode, 30(8). https://doi.org/10.1111/j.1467-8330. 1976.tb00636.x

Lefebvre, H. (1976b). The survival of capitalism: Reproduction of the relations of production. Allison \& Busby.

Maldonado-Torres, N. (2007). On the coloniality of being. Cultural Studies, 21(2-3). https://doi.org/10.1080/ 09502380601162548

Mama, D., \& Anderson, C. (2016). Decolonisation and food sovereignty in Europe, thoughts from the edges. https://www.peoplesknowledge.org/discussions-on-decolonising-food-food-sovereignty-in-europe/

Margulis, M., Mckeon, N., \& Borras, S. (2013). Land grabbing and global governance: Critical perspectives. Globalizations, 10(1), 1-23. https://doi.org/10.1080/14747731.2013.764151

Marks, S. (2003). Empire's law (the Earl A. Snyder lecture in international law). Indiana Journal of Global Legal Studies, 10(1). https://doi.org/10.2979/gls.2003.10.1.449

Mattei, U., \& Capra, F. (2015). The ecology of law: Toward a legal system in tune with nature and community. Berrett-Koehler Publisher.

Mattei, U., \& Nader, L. (2008). Plunder: When the rule of law is illegal. Blackwell Publishing.

Mbembe, A. (2013)., Critique of black reason. Duke University Press.

Mignolo, W. D. (2007). Coloniality of power and de-colonial thinking. Cultural Studies, 21(2-3), 155-167. https://doi.org/10.1080/09502380601162498

Mignolo, W. D. (2011). The darker side of western modernity: Global futures, decolonial options. Duke Press.

Moore, J. W. (2015). Capitalism in the web of life: Ecology and the accumulation of capital. Verso Books.

Morden, M. (2015). Rights and resistance: Norms, interests and indigenous direct action in Canada. Ethnopolitics, 14(3), 256-376. https://doi.org/10.1080/17449057.2014.949444

Morris, R. C. (Ed.). (2010). Can the subaltern speak? Reflections on the history of an idea. Columbia University Press.

Moyn, S. (2018). Not enough. Harvard University Press.

Patel, R., \& Moore, J. W. (1983). History of the world in seven cheap things. Verso Books.

Polanyi, K. (2001). The great transformation. The political and economic origins of our times. Beacon Press.

Quijano, A. (2000). Coloniality of power and Eurocentrism in Latin America. International Sociology, 2(15). https://doi.org/10.1177/0268580900015002005

Quijano, A. (2007). Coloniality and modernity/rationality. Cultural Studies, 21(2-3).

Rajagopal, B. (2003). International law from below: Development, social movements and third world resistance. Cambridge University Press.

Sammond, N. (2007). Commodities, commodity fetishism, and commodification. In G. Ritzer (Ed.), The Blackwell encyclopedia of sociology (pp. 607-612). Blackwell Publishing.

Sassen, N. S. (2013). Land grabs today: Feeding the disassembling of national territory. Globalizations, 10(1), 25-46. https://doi.org/10.1080/14747731.2013.760927 
Sassen, S. (2014). Expulsions: Brutality and complexity in the global economy. Harvard University Press. Shiva, V. (1993). Monocultures of the mind. Zed Book.

Tarrow, S. (1994). Power in movement: Social movements, collective action and politics. Cambridge University Press.

Tsing, A. (2002). Land as law: Negotiating the meaning of property in Indonesia. In J. F. Richards (Ed.), Land, property and the environment (pp. 94-137). Institute for Contemporary Studies.

Vivero-Pol, J. L., Ferrando, T., Schutter, O., \& Mattei, U. (2018). Routledge handbook of food as a commons. Routledge.

Wallerstein, I. (1983). Historical capitalism. Verso.

White, B. (2012). The new enclosures: Critical perspectives on corporate land deals. Journal of Peasant Studies, 39(3\&4), 619-647. https://doi.org/10.1080/03066150.2012.691879

Zibechi, R. (2010). Dispersing power. Social movements as anti-states forces. AK Press.

Zibechi, R. (2012). Territories in resistance: A cartography of Latin American social movements. AK Press. 